\title{
Measuring Losses For Small Business Interruption Claims: Depreciation Expenses
}

Denis O. Boudreaux, University of Louisiana, USA SPUma Rao, University of Louisiana, USA

Jim Underwood, University of Louisiana, USA

Nancy Rumore, University of Louisiana, USA

\begin{abstract}
Business interruption insurance, commonly called lost profit insurance is written to protect a firm when its operations are interrupted and income is reduced due to a covered peril. The calculation of the economic loss depends on how certain expenses are used in the loss computation. Depreciation is an expense that can have significant implications on the measure of the loss figure but how depreciation should be accounted for is not specified in policies or law. This paper reviews the depreciation controversy and offers a more theoretically correct solution.
\end{abstract}

Keywords: Measuring Business Interruption Losses; Accounting for Depreciation in Business Interruption Claims; Review of Approaches to Calculate Business Interruption Losses

\section{INTRODUCTION}

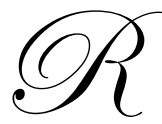

ecent major natural disasters such as Hurricanes Katrina and Rita in the Gulf Region, raging fires in the western states and dangerous flooding in the central U.S. have caused a dramatic increase in business interruption insurance claims. When the twin towers of the World Trade Center came down in September 11, 2001, it cost the insurance industry over 36 billion dollars (Hartwig 2006). What may surprise many is that the largest insurance payout was not for property claims, but for business interruption (Mowbray 2006). The 2010 tragic oil disaster in the Gulf of Mexico most likely will result in many billions of dollars of lost income for business and spur many business interruption insurance claims. Business interruption insurance is designed to indemnify the insured business against losses arising from its inability to continue its normal operations (Hammond 1999). It is documented that business owners insured their operations as long ago as 1750 B.C. when traders from Babylonia had the Code of Hammurabi (eHOW). A merchant who borrowed money paid a fee to the lender to have the right to cancel the loan in the event there was a loss. Today, business interruption coverage is generally provided by an endorsement or rider to a commercial property insurance policy.

\section{BUSINESS INTERRUPTION INSURANCE}

Business interruption insurance is an essential component of a firm's insurance coverage program (Brennan and Conway 2003). Commercial property insurance claims often involve more than a loss of fixed assets or tangible business property from a covered peril. Economic damages in the form of lost income from suspended operations along with extra expenses due to the peril are commonly part of the commercial loss. The purpose or intention of business interruption coverage is to allow the insured to resume its normal business operations as soon as possible. Most business interruption policies reimburse the policy holder for loss of income and payment for certain fixed and continuing expenses. Recovery under both the general business interruption coverage and extra expense coverage is limited, in part, to the period required to restore operations (Long and Trotter 2010). Case law is very clear that the coverage is not to put the insured in a better position than prior to its loss (37 A.LR. $5^{\text {th }} 41$ 2001). This type of insurance provides loss of income coverage for a business by replacing operating profit during a period when damage to its business premises or other property prevents it from earning income. To constitute a recoverable business interruption loss under the typical standard insurance contract, five criteria must normally be met (Peterson 2008). The criteria are: 1) the insured must have suffered physical damage; 2) the damage must have occurred to 
insured property; 3) the damage must have been caused by a covered peril; 4) the damage must have resulted in a measurable business interruption loss; and 5) that measurable business loss must occur during the period required to reasonably and diligently restore the damaged property.

In general, it is a policy requirement that the insured make reasonable efforts to mitigate its loss. To help mitigate the loss business interruption policies often provide coverage for the "extra expenses" that the insured incurs to reduce the loss and quickly resume normal business operations. These additional expenses include such items as moving costs, rent for temporary locations, and extra compensation for overtime work, higher utility charges incurred at a temporary location, payments made to accelerate repairs to damaged property, and the like.

Insurance companies prefer to settle business interruption claims in a quick and satisfactory manner without litigation, media exposure and large administrative and legal expenses. However, even in the best of circumstances, experts say, business interruption claims entail complex calculations to establish what a business would have earned without the covered peril and quantifying how much the business suffered because of it---such an analysis is inherently speculative and ripe for challenge (Mowbray 2006). When an acceptable settlement cannot be reached by the involved parties, the insured, and the insurance company, hire attorneys and forensic economic or accounting experts to represent their interests. These experts estimate and report the lost income or profit that is due to the insured according to their interpretation of coverage stated in the insurance policy contract. The experts and adjusters must prepare a thorough and accurate analysis as they may be required to present their findings to mediators or in court proceedings.

The forensic experts generally use the firm's historical financial statements and records to estimate the decline in revenues and changes or declines in the associated or matched expenses to estimate the loss. Almost all economists agree that the true variable costs that would have occurred but did not occur because of the peril are not covered and not to be compensated because they were avoided due to interrupted operations. Also, experts concur that fixed costs such as rent, salaries, etc., that continue after the peril are covered for the period of restoration or the maximum coverage period. There appears to be no consensus among experts, however, as to how depreciation expense should factor in the calculation of business loss..

How to treat depreciation expense has not satisfactorily been established in the typical insurance contract nor has it been entirely addressed in the courts. The alternate ways depreciation expense can be used in the lost income calculations can have a significant financial impact on the total dollar loss distribution or payout. There is a group of experts who believe that the lost depreciation expense during the period when the operations are less than would be normally, should be part of the recovery. Another group of experts expound that depreciation expense should not be included as part of the settlement. All most all economists believe the continuing fixed cost expenses such as salaries, rent, etc. if actually continued and were paid are covered under the insurance contract. This paper discusses the different divisive views on the proper way to use depreciation expense and presents a more theoretically correct model to calculate business interruption losses. It also provides an example illustrating how this model's treatment of depreciation and other expenses affects the calculation of a business interruption loss.

\section{ARGUMENTS AGAINST INCLUDING DEPRECIATION}

Most insurance adjusters' and some economists' position is that when a covered peril that destroyed an asset also results in a business loss due to an interruption in operations, the depreciation on the ruined asset ceased and cannot be considered a recoverable continuing expense during the period of interruption (O'Connell et al 1995). In a loss settlement situation, often the insurance adjuster's argument is that some portion, if not all, of the reduction in depreciation expense during the interruption period is a saved expense. Thus depreciation should be deducted from the lost gross earnings (reducing the settlement) in arriving at the ultimate business interruption claim. The argument often presented is that depreciation is a charge to earnings to reflect the wear and tear on the facilities and this wear and tear did not occur and was saved during the disruption period. If the asset was destroyed, then the property insurance portion of the insurance contract will reimburse the insured based on the insurance coverage (market value, insured value or replacement value). When the insurer compensates the insured for the destroyed property, the asset being reimbursed for is effectively sold or transferred to the insurance company. The business will record a gain on its accounting books for the amount of insurance proceeds that exceeds the remaining un- 
depreciated cost of the old asset. The insurance companies argue that in the majority of cases, the settlement provides adequate funds to replace the destroyed asset. The economists that support the premise that depreciation should not be reimbursed, opine, that the insured has already recovered the current value of the asset if not more and therefore should not be entitled to any additional recovery, such as continued depreciation, under the business interruption coverage. The insurance company points out that the firm is compensated with the property insurance settlement which is actually a part of the remaining depreciation so additional depreciation should not be taken and included in the business interruption claim. They believe that the insured would be put in a better position than if the loss had not occurred violating the basic objective of insurance. Courts have held that an insured may not include depreciation as an expense under a business interruption policy where the business property has been totally destroyed since depreciation only involves the useful life of an asset (573 N.E.2d 851 1991). However, in another case when the insurance company deducted depreciation as a non-continuing expense, the court allowed the insured to include depreciation expense as recoverable. The court found that for an apartment building owner, depreciation is solely a tax device and is not considered a non-continuing expense (604 N.E. 2 d 942 1992). The court allowed depreciation to be reimbursed.

\section{ARGUMENTS FOR INCLUDING OF DEPRECIATION}

The intent of business interruption insurance proceeds are to return the insured to the same financial position had the loss not occurred. The economists that believe depreciation is a reimbursable expense argue that depreciation would have occurred had there been no event so it is reimbursable. After all what really matters is the ultimate economic position of the firm. The deprecation would have provided a benefit to the firm. As stated earlier, generally, upon receipt of physical damage insurance proceeds, the insured will book an accounting gain on the "disposal" of its destroyed assets. This gain is the amount by which the physical damage proceeds exceed the remaining net book value of the assets at the time of the loss. This gain is undoubtedly a non-cash flow item. To make use of the adjuster's reasoning in the position that depreciation should not be included, the economist should propose to deduct "saved depreciation," which would result in a further reduction to the business interruption claim adjusted for this non real gain (O'Connell et al 1995). It is clear to almost all that this would be an unacceptable adjustment to the calculation of the loss amount.

\section{A MORE THEORETICALLY CORRECT APPROACH}

The American Institute of Certified Public Accountants defines depreciation as follows (Accounting Research Bulletin No. 43):

A system of accounting that aims to distribute the cost or other basic value of tangible capital assets less salvage (if any), over the estimated useful life of the unit (which may be a group of assets) in a systematic and rational manner. It is a process of allocation not of valuation.

This definition is a theoretical description of what depreciation should actually accomplish in the AICPA's opinion. In reality, because of the many different GAAP depreciation methods to select from, actual annual depreciation expense has little to do with the reduction in the useful life of the asset. The AICPA believes depreciation is an application of the fundamental accounting principle of matching revenues with its respective costs. Each period of time that obtains the beneficial use of an asset is charged with an appropriate share of its total cost less salvage value. So, depreciation represents a decline in service potential of an asset which may be the result of physical deterioration, inadequacy due to increased demands resulting from higher production volume, consumption through use, or loss in economic value due to obsolescence. In practice, businesses use the most accelerated depreciation method as possible for tax reasons to reduce their current tax liability. Although depreciation is not an actual cash flow, depreciation affects cash flow by reducing the firm's tax obligation making more cash available to the business.

After receipt of physical damage insurance proceeds, the insured will book an accounting gain on the proceeds that exceeded the remaining net book value of the assets. If the insurance proceeds are less than the net book value, which seldom occurs, the firm will record a loss. Any gains are actually paper gains and undoubtedly a non-cash flow transaction. The gain is going to be recorded as income to the business and taxed and thus generates a 
cash outflow to the firm.

Small not publically owned businesses normally only prepare one set of books and that is the financial reports or statements for tax purposes. The accounting impact of an insured incident is that lower amounts of depreciation will be expensed during the interruption period than otherwise would be the case had no incident occurred. In cases where the businesses operations have completely shut down or stopped, no depreciation will be charged.

Business interruption insurance is financial protection designed to place the insured in the same financial shape or position because of an incident that has caused a reduction in revenues and profits. As indicated earlier, depreciation is an accounting charge for the allocation of the cost of a fixed asset that reduces a firm's taxable income and thus its taxes. The deduction of depreciation in a loss income claim would violate the underlying concept of indemnity inherent in a business interruption insurance policy as the firm is worst off because the settlement payment is going to be less than the firm's operating cash flow had there been no incident . A firm's Cash Flow from Operations (CFfO) is equal to income after taxes plus any non-cash flow charges such as depreciation and is presented in an equation below (Gitman 2010).

$\mathrm{CFfO}=$ Net Profit after Taxes + Depreciation and Other Noncash Charges

CFfO is the measure of earning power for the firm. This is a basic finance equation and Cash Flow from Operations is often used as a key variable in business valuation litigation or company takeover decisions.

The true economic loss for business interruption is the measure of the decline or decrease in the firm's Cash Flow from Operations resulting from the insured peril. The loss can be expressed in the equation below:

Change/Decline in CFfO $=$ CFfO with No Loss Event $-\mathrm{CFfO}$ with Loss Event

The model requires the expert to measure what the Cash Flow from Operations would have been had there been no peril and loss and subtract what the Cash Flow from Operations are given the damaging event. The expert will review the firm's historical financial records, perform a macro and micro analysis of the market, evaluate the industry and project what the revenues would have been (Gaugham 2009). The expert will then trace appropriate variable expenses to estimated revenue and subtract them from it to arrive at Net Income and CFfO. Adding taxes and continuing fixed expenses, e.g., rent and salaries, to CFfO, the expert will arrive at the appropriate value of lost income.. The model to derive CFfO is similar to the valuation model to measure lost profits in business damage cases (Zukin 1990) and the discounted cash flow model -in valuing a firm (Pratt et al 1996). The loss for business interruption, however, is for less than a year whereas lost profits in damage cases and expected cash flows for business valuation purposes extends years into the future.

\section{BUSINESS DESCRIPTION FOR EXAMPLE}

A small, privately owned manufacturing (ABC Manufacturing, Inc) firm's operating facility, including its plant and machinery, was completely destroyed by an insured peril, an explosion and fire. The relevant insurance policy provisions are provided in the appendix. ABC manufactured disposable bags for popular vacuum cleaners. The firm had to completely cease its operations until the plant could be rebuilt and new machinery reinstalled (time to reinstate the plant is estimated to be one year). The firm, an S Corporation prepared and maintained only one set of financial statements which were for tax purposes. The most recent yearly income tax return (1120S) which can and should be used as the pro forma income estimate for the year of non-operations is found in Exhibit I. To make the case simple, an assumption is that there were to be no growth in sales nor any increases in expenses for the year 2010, the year of non-operations (if there was reason to believe this is not the case, the economist should adjust all accounts that were not going to be the same). Also, the explosion and ensuing fire occurred on December 31, 2009 the last day of the fiscal year and the plant was idle for the holiday (no lost income for the day). 


\section{FINANCIAL INFORMATION}

The first step in analyzing the economic loss to a firm for loss of profit/income insurance purposes is to measure the firm's reduction in sales or lost sales. All expenses that would have occurred to produce the lost income must next be determined. Fixed cost expenses that would have been charged against the lost income would also be identified. A pro forma income statement would then be prepared to measure the firm's loss in income, its reduction in after tax income and the decrease in cash flow from operations. This decline in cash flow from operations figure is the firm's true economic loss from operations. To this figure, all ongoing cash expenses that continued to occur relevant to the reduction in operations would be added to get the total economic loss.

Exhibit I presents the firm's income statement from the firm's filing U.S. Income Tax return for an S Corporation, for the latest year, 2009. This filing is also the firm's expected earnings for 2010 and is used as its pro forma income statement, had there been no catastrophic accident and total destruction of the firm's physical assets.

\section{EXHIBIT I \\ ABC MAUFACTURING, Inc. \\ INCOME STATEMENT, FORM 1120S \\ 2009}

\begin{tabular}{|c|c|c|c|}
\hline & \multirow{2}{*}{\multicolumn{2}{|c|}{$\begin{array}{l}\text { Revenue } \\
\text { Cost of Goods }{ }^{1}\end{array}$}} & $\$ 10,000,000$ \\
\hline & & & $\underline{6,000,000}$ \\
\hline & \multicolumn{2}{|l|}{ Gross Profit } & $4,000,000$ \\
\hline & \multicolumn{2}{|c|}{ Compensation of Officers } & 100,000 \\
\hline & \multicolumn{2}{|l|}{ Salaries } & 900,000 \\
\hline & \multicolumn{2}{|c|}{ Repairs and maintenance } & 400,000 \\
\hline & \multicolumn{2}{|l|}{ Bad Debt } & 0 \\
\hline & \multicolumn{2}{|l|}{ Taxes and Licenses } & 1,000 \\
\hline & \multicolumn{2}{|l|}{ Interest } & 400,000 \\
\hline & \multicolumn{2}{|l|}{ Depreciation } & 800,000 \\
\hline & \multicolumn{2}{|l|}{ Advertising } & 500,000 \\
\hline & \multicolumn{2}{|l|}{ Pension } & 0 \\
\hline & \multicolumn{2}{|l|}{ Other } & $\underline{20,000}$ \\
\hline & \multicolumn{2}{|l|}{ Total Deductions } & $\$ 3,1 \overline{21,000}$ \\
\hline & \multicolumn{2}{|l|}{ Taxable Income } & $\$ 879,000$ \\
\hline & \multicolumn{2}{|l|}{ Taxes $(40 \%)$} & $\$ 351,600$ \\
\hline & \multicolumn{2}{|l|}{ Net Income } & $\$ 527,400$ \\
\hline & \multicolumn{2}{|c|}{ ADD Back Depreciation } & $\$ 800,000$ \\
\hline & \multicolumn{2}{|c|}{ Cash Flow from Operations (CFfO) } & $\$ 1,327,400$ \\
\hline 1 & Beginning Inventory & $\$ 2,000,000$ & \\
\hline & Purchases & $\$ 3,000,000$ & \\
\hline & Ending Inventory & $\$ 1,000,000$ & \\
\hline & Direct Labor & $\$ 2,000,000$ & \\
\hline & Cost of Goods & $\$ 6,000,000$ & \\
\hline
\end{tabular}




\section{EXHIBIT II}

ABC MAUFACTURING, Inc.

PRO FORMA INCOME STATEMENT, FORM 1120S

PERIOD OF LOSS 2010

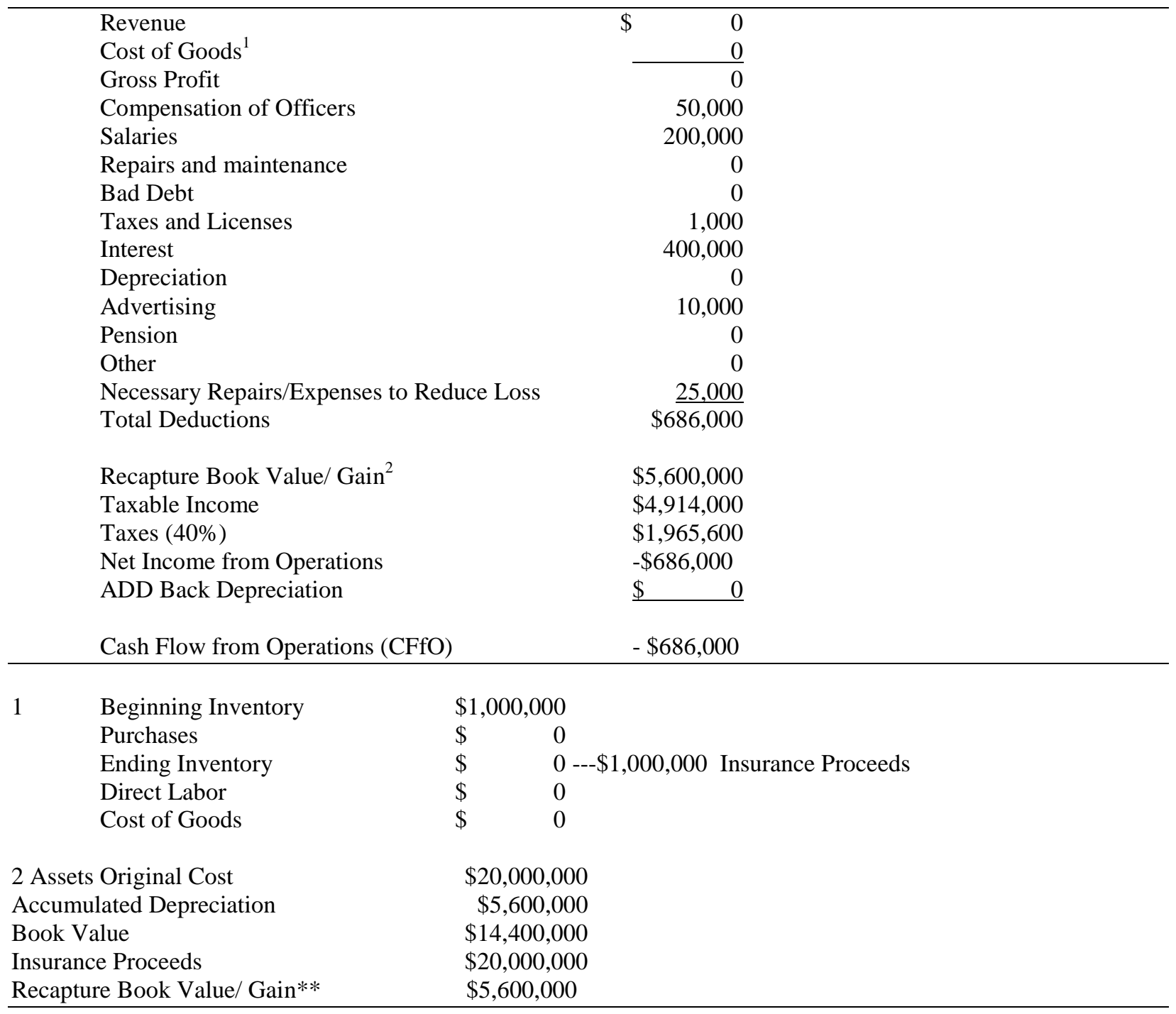

\section{ECONOMIC ANALYSIS EXCLUDING DEPRECIATION}

The economic analysis approach that excludes depreciation is based on the principle that the firm is going to be compensated for the fixed assets that were damaged or destroyed and that no depreciation will occur during the loss period. Under this premise, the economist is considering the impact of the firm's property and casualty insurance coverage while evaluating the coverage under the profit/income loss insurance contract. A template illustrating the loss calculation under this method is shown in Exhibit III. 


\title{
EXHIBIT III \\ ABC MAUFACTURING, Inc. MEASURE OF LOSS EXCLUDING DEPRECIATION \\ 2010
}

1. Net Income

$\$ 527,400$

2. Add Taxes

$\$ 351,600$

3. Plus Cash Expenses that continued to Occur (Exhibit 2)

Compensation of Officers

\author{
2)
}

Salaries

Repairs and maintenance

Bad Debt

Taxes and Licenses

Interest

Depreciation

Advertising

Pension

Other

Necessary Repairs to Reduce Loss

TOTAL

50,000
200,000
0
0
1,000
400,000
$\mathrm{NA}$
10,000
0
0
25,000

EQUALS THE ECONOMIC LOSS/DISTRIBUTION

$\underline{\$ 686,000}$

\section{ECONOMIC ANALYSIS INCLUDING DEPRECIATION}

This approach argues that had not there been the loss incident, the firm would have had a certain level of sales and expenses including depreciation. These transactions would have determined the firm's taxes, and profits. The economists that favor this methodology argue the firm should recover its lost depreciation.

A template illustrating the loss calculation under the method including depreciation is shown in Exhibit IV.

\section{EXHIBIT IV \\ ABC MAUFACTURING, Inc. \\ MEASURE OF LOSS INCLUDING DEPRECIATION \\ 2010}

1. Net Income

2. Add Taxes

3. Plus Cash Expenses that continued to Occur (Exhibit 2)

Compensation of Officers

Salaries

Repairs and maintenance

Bad Debt

Taxes and Licenses

Interest

Advertising

Pension

Other

Necessary Repairs to Reduce Loss

TOTAL

$\$ 527,400$

$\$ 351,600$

$\$ 1,565,000$

$\begin{array}{ll} & \$ 527,400 \\ & \$ 351,600 \\ 50,000 & \\ 200,000 & \\ 0 & \\ 0 & \\ 1,000 & \\ 400,000 & \\ 10,000 & \\ 0 & \\ 0 & \\ 25,000 & \\ & \$ 686,000 \\ & \$ 800,000 \\ & \frac{\$ 1,486,000}{\$ 2,365,000}\end{array}$




\section{A MORE THEORETICALLY CORRECT APPROACH}

To estimate the business interruption loss, a pro forma income statement should be prepared representing what the revenues and expenses would have been had there been no event and compare to what the firm's actual performance. For this example, the firm's last year of operations, 2009 is the estimate for the firm's 2010 performance. Exhibit $\mathrm{V}$ shows the most theoretically correct measure of business interruption loss. Cash Flow from Operations from the Pro form Income Statements with and without the loss is used to measure of the business interruption loss.

\begin{tabular}{|c|c|}
\hline $\begin{array}{c}\text { EXHIBIT } \\
\text { BUSINESS INTERRUI }\end{array}$ & \\
\hline 1. Cash Flow from Operations without Loss & $\$ 1,327,400$ \\
\hline 2. Minus Cash Flow from Operations With Loss & $-\$ 686,000$ \\
\hline TOTAL LOSS for Cash Flow from Operations & $\$ 2,013,400$ \\
\hline 3. Add Taxes ${ }^{1}$ & $\$ 884,933$ \\
\hline EQUALS THE ECONOMIC LOSS/DISTRIBUTION & $\$ 2,898,333$ \\
\hline
\end{tabular}

1. The firm will pay taxes on the cash flow from operations loss distribution of $\$ 1,327,400$ and on the distribution for the firm's tax obligation. The distribution of $\$ 686,000$ is offset by the loss or negative profit for 2010 of $\$ 686,000$. The amount needed to compensate the firm for its loss in cash flow from operations is thus $\$ 1,327,400$ divided by $60 \%$ which is $\$ 2,212,333$. The taxes will be $\$ 884,933$ leaving a residual which is the firm's out of pocket cash flow of $\$ 1,327,400$.

\section{CONCLUSION}

If depreciation is not included in the calculation of the business interruption loss, the settlement or distribution is estimated to be $\$ 1,565,000$. If deprecation is accounted for and included in the analysis, the loss is calculated to be $\$ 2,365,000$. The theoretically correct model advocated in this paper employs Cash Flow from Operations and results in a loss figure of $\$ 3,898,333$. For the three approaches, the loss estimates differ significantly. The theoretical basis for the depreciation exclusion approach is that the firm is being compensated for the damaged assets under the property provisions of the insurance policy and thus should not be also awarded for deprecation that is not actually occurring under the business interruption clause. This thesis is not theoretically correct. The firm entered into a contract with the insurance company with provisions to cover the property of the firm and with an endorsement to protect against business interruption. The intentions of the insurance contract are to restore the insured to the same position before the loss occurred. This includes tangible assets and lost profit/income.

The second approach that included depreciation in its measure of business damages is better than the nondepreciation method but does not fully account for all of the loss. Net income or profit for a firm can vary drastically for a given or specific level of sales due to the selection of General Accepted Accounting Procedures. Different selections of inventory valuation and choices of depreciation methods for the exact same level of sales can dramatically impact the measure of profit. Two firms, that are identical in every way, may have significantly different taxable income based on their choices of legally acceptable depreciation (Bowles and Lewis 1997). It is well established in the financial literature that cash flow is the most theoretical correct variable to measure a firm's value. It is our position that the depreciation method the firm had been using and would have used had there been no business interruption must be used in the measure of loss. Theoretically and operationally a firm selects a depreciation method that maximizes the value of the firm (Van Horn 1995). This depreciation method selected will minimize the firm's current taxes and maximize the firm's cash flow from operations. Therefore, the expert should select the depreciation method that the firm would have used that would optimize cash flow and value. What is important to the firm is not an artificial accounting figure called lost profits but the difference in cash flow to the firm. To properly measure the difference or reduction in cash to the firm, the calculation of the difference in cash flow from operations has to be determined. For the sample, the firm's true loss in cash flows from operations, that is, what the firm would have had compared to what it will have is the difference of $\$ 2,013,400$. Therefore, a 
settlement payment of $\$ 2,898,333$ will place the firm in the same economic and operating position as though the covered peril and loss had not occurred. Of the $\$ 2,898,333$ payment, $\$ 884,933$ will go to taxes and the remaining balance of $\$ 2,013,400$ will be retained by the firm.

\section{AUTHOR INFORMATION}

Denis O. Boudreaux is an Associate Professor of finance at the University of Louisiana at Lafayette. He teaches the financial management case course and the MBA advanced finance course. Some of his research interests include capital market efficiency, capital budgeting and valuing and measuring the cost of capital for small privately held firms. $\mathrm{He}$ has published in many refereed journals including Business and Economic Review, Journal of Business \& Economics Research, Southwestern Economic Review and The Journal of Economics and Finance. Dr. Boudreaux is a practicing forensic economist and testifies in personal injury and commercial damage cases.

S.P. Rao is a full professor at the University of Louisiana at Lafayette. He teaches investment and portfolio management courses. His research interests are in the field of investments, especially asset pricing, portfolio theory, optimization and capital market efficiency. Dr. Rao has published in many peered reviewed journals such as Journal of Business Ethics, Global Finance Journal, Managerial Finance, Southwestern Economic Review, Journal of Economics and Finance, International Business \& Economics Research Journal and The Journal of Accounting and Finance Research.

Nancy C. Rumore is an instructor in Economics at the University of Louisiana a Lafayette. She teaches Fundamentals of Economics to non-business majors and Principles of Economics to business majors. She has published in many referred journals including The Journal of Financial and Strategic Decisions, The Journal of Bank Cost and Management Accounting The Journal of Business and Economics Perspectives, Multinational Business Review, Atlantic Economic Journal, Journal of Economics and Finance and The Journal of Restaurant and Foodservice Marketing.

James H. Underwood III is associate professor of marketing in the department of Marketing and Hospitality at the University of Louisiana, Lafayette. Dr. Underwood has numerous publications in marketing and business journals. He has served as an expert witness in many business loss and personal injury cases. Among his research interests are forensic marketing and economic analysis, marketing management, distribution channels, marketing research methods and marketing engineering.

\section{REFERENCES}

1. $\quad$ Accounting Research Bulletin No. 43, Chapter 9, June 1953.

2. Bowles, Tyler J. and W. Cris Lewis, "Tax Returns as the Basis for Lost Profit Appraisals: Possible Adjustments," Litigation Economic Digest, II (1997), pp. 112 - 124.

3. Brennan, Robert J. and Laura C. Conway. "Business Income Insurance Coverage," The Brief, 32. No 4, Summer 2003.

4. "Definition of Business Income Insurance," (n.d.). Retrieved from http://www.ehow.com/about 5138593 definition-business-income-insurance.html\#ixzz0wE9Lzmed.

5. $\quad$ Gaugham, Patrick A., Measuring Business Interruption Losses and Other Commercial Damages, $2^{\text {nd }}$ ed., New Jersey: John Wiley \& Sons, Inc., 2009.

6. Gitman, Lawrence J., Principles of Managerial Finance 12th ed., New York: Harper Collins, 2009.

7. Hammond, Rick L., "Underlying Principles of Business Interruption Insurance," 1999. Retrieved from http://library.findlaw.com/1999/Jun/1/127909.html.

8. Hartwig, Robert P., "9/11 and Insurance: The Five Year Anniversary," 2006. Retrieved from http://server.iii.org/yy_obj_data/binary/760752_1_0/September\%2011\%20Anniversary.pdf.

9. Long, Geoffrey M. and Kenneth Berline Trotter. Business Interruption Insurance: Calculation of the "Period of Restoration" Must Be Informed by Post-Loss Challenges," Property Insurance Law Committee Newsletter, Spring 2010, pp $8-11$.

10. Mowbray, Rebecca. (September 17, 2006). World Interrupted. The Times-Picayune, p. 1. 
11. O'Connell, William D., Harvey N. Michaels, Chris Campos and Raymond J. McErlean, "Depreciation: Is it a Saved Expense in a Business Interruption Claim?" Claims Magazine, September 1995.

12. Peterson, James and Angela Krahulik, "Business Interruption Insurance Midwest Floods Have Caused an Unprecedented Amount of Damage," June 2008. Retrieved from http://www.icemiller.com/enewsletter/June08/BusinessInterruptionInsurance.htm.

13. Pratt, Shannon P., Robert F. Reilly, and Robert P. Schweihs. 1996. Valuing a Business: The Analysis and Appraisal of Closely Held Companies (3rd ed.). Chicago: Irwin Professional Publishing

14. Van Horn, James C. 1995. Financial Management and Policy (10th ed.). Englewood Cliffs: Prentice Hall.

15. Zukin, James H., ed. 1990. Financial Valuation: Businesses and Business Interests (with 1998 Cumulative Index). New York: Warren Gorham \& Lamont/RIA Group. 